\title{
Implementation of the Developed Pharmaceutical Indonesian Language Textbooks with Scientific Approach in Indonesian Language Subject in Pharmacy Vocational Schools, Kendal Regency
}

\author{
Angela Diyansih Wisesa Chuntala, Yuliana Setyaningsih
}

\begin{abstract}
This study aims to determine the effectiveness of the implementation of the developed pharmaceutical Indonesian language textbooks with Scientific Approach in Indonesian language subject in Pharmacy Vocational Schools in Kendal Regency. This study was a quasi-experimental design on the implementation of the developed pharmaceutical Indonesian language textbooks to all grade ten students of the Pharmacy Vocational Schools. Respondents of this study were 97 students who took part in learning using the Ministry of Education and Culture's textbooks and the developed pharmaceutical textbooks with scientific approach. The t-test results at 0.005 significance level indicate that the implementation of the developed pharmaceutical Indonesian language textbooks with scientific approach is effective because it has an effect on improving the Indonesian language learning outcomes. Students' average scores of learning outcomes have increased by learning using the pharmaceutical Indonesian language textbooks. Students' learning outcomes from the five schools have increased as follow: (1) student learning outcomes at Azzahro vocational school increased by 4.45; (2) an increase of 9.17 in student learning outcomes at Bhakti Kencana vocational school; (3) an increase of 5.42 in student learning outcomes at Insan Medika vocational school; (4) an increase in student learning outcomes at Ngesti Widhi vocational school by 5.77; and (5) an increase in student learning outcomes at Taman Siswa Boja vocational school by 4.60. The increase in the score indicates that the implementation of the developed pharmaceutical Indonesian language textbooks with scientific approach for grade ten students of the Pharmacy Vocational Schools is feasible because it has a positive effect on the student learning outcomes.
\end{abstract}

Keywords: Implementation of Development Results, Pharmaceutical Textbooks, Scientific Approach

\section{INTRODUCTION}

Education is a learning process through formal and non-formal activities that aim to develop individuals in terms of cognitive, affective and psychomotor aspects. In line with

* Correspondence Author

Angela Diyansih Wisesa Chuntala*, Master Program of Indonesian Language Education, Sanata Dharma University, Yogyakarta, Indonesia. Email: achuntala76@gmail.com

Yuliana Setyaningsih, Master Program of Indonesian Language Education, Sanata Dharma University, Yogyakarta, Indonesia. Email: yuliapbsi@gmail.com

(c) The Authors. Published by Blue Eyes Intelligence Engineering and BY-NC-ND license (http://creativecommons.org/licenses/by-nc-nd/4.0/)
Revised Manuscript Received on October 13, 2020. Sciences Publication (BEIESP). This is an open access article under the CC

this idea, learning is viewed as a process that a person does deliberately and is managed to enable the person to participate in certain behaviors (Setiawati, 2016). Jayanti further emphasized that learning is carried out in order to achieve a behavior or competence in students after participating in the teaching and learning activities (Jayanti, 2019). Teaching and learning activities as education support cannot be separated from inter-related components. One of the supporting components of teaching and learning activities is teaching materials. Teaching materials are very important for both teachers and students in the learning process. Without teaching materials, it will be difficult for teachers to deliver learning. Likewise, it will be difficult for students to adjust themselves in the learning process with or without a teacher (Agustina, 2015). Teaching materials are all materials used by teachers to facilitate students in the learning process. Teaching materials can also be in the form of newspapers, food packages, photos, direct speeches by native speakers, teacher explanations, assignments and live group discussions (Eriyanti, 2018).

\section{THEORETICAL BACKGROUND AND REVIEW OF THE RELATED LITERATURE}

Textbooks are the main teaching materials, considering that each subject must have a textbook as a handbook (Iskandar, 2016). Apart from serving as handbook, textbooks are also one of the educational media with a strategic position so that they also affect the quality of education because they can function as learning resources and very important media to support the achievement of competencies which become the learning objectives (Banowati, 2007). Permendiknas No. 20 of 2008 Article 1 explains that textbooks are mandatory reference books to be used in primary, secondary and higher level education units that contain a subject matter in order to increase faith, piety, noble character, personality and mastery of technology and science (Rochmayanti, 2012).

The existence of teaching materials is very helpful for teachers in carrying out the teaching and learning activities, so that the materials can be delivered well (Nugroho, 2019). Considering that materials play an important role in on-going learning activities, the materials should be presented in depth and should represent the learning content. The results of a preliminary study in Pharmaceutical Vocational Schools in Kendal Regency show that the teachers have taught well.

Blue Eyes Intelligence Engineering \& Sciences Publication

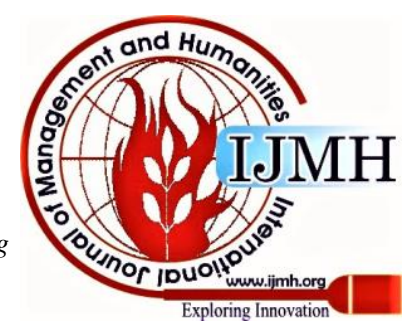


The teachers are able to deliver the materials in depth; the teaching materials used are various and are adjusted to the topics being taught. From the information obtained through the preliminary study, it is found that the textbooks that are used by teachers and students in learning Indonesian language still need to be developed, both in terms of the materials scope and provision of assignments. The textbooks that have been used as the teachers' guide in learning Indonesian language by the Pharmacy Vocational School students are still very general. Materials related to pharmacy, both in the form of images, photos, charts, schemes and texts that are in accordance with the achievement indicators of graduates in Pharmacy Vocational Schools need to be reviewed. It is important considering that Indonesian language subject is a compulsory subject at every level of education, as well as at the vocational schools. It would be wise to adjust the provision of learning textbooks at vocational schools with the particular department. Learning that is prepared and delivered according to the major taken will certainly help students understand the terms and contents better (Iskandar, 2016). the Indonesian language teachers and the grade ten students of Pharmacy Vocational Schools in Kendal Regency. The statement in the interview is also related to the government regulations regarding the achievements of vocational school graduates that expect students to be ready to work according to the major that they choose. Thus, the implementation of the developed pharmaceutical Indonesian language textbooks with scientific approach in Pharmacy Vocational Schools in Kendal Regency is important to conduct so that it can help vocational school students familiarize themselves with all things that are related to their major. Sitepu (2005) said textbooks are one of the learning resources that have major contributions in expanding the opportunities for education as well as improving the learning outcomes.

Language has a central role in the intellectual, social and emotional development of students and can support success in learning all fields of study. Language learning is expected to help students know themselves, their cultures, express their ideas and feelings, participate in communities that use the language, as well as discover and use analytical and also imaginative abilities that exist within themselves. These things are in accordance with the basic competencies of Indonesian language subject which are the minimum qualifications of students' abilities that describe the mastery of knowledge, language skills and a positive attitude towards language and literature. Therefore, Indonesian language learning in the 2013 Curriculum does not only function as a tool of communication, but also as a tool of thinking. Indonesian language learning in elementary schools until high schools as well as universities focuses on text-based learning. Text is an expression of the human thoughts that is completed with the situation and context (Mursida, 2017). Therefore, Indonesian language learning in vocational schools is very important to be related to the vocational context. Efforts to relate Indonesian language learning with a pharmaceutical context can help students to be more motivated in achieving the expected competencies.

The 2013 curriculum also emphasizes the modern pedagogical dimension of learning by using the scientific approach. The scientific approach is used throughout the 2013 Curriculum to improve the learning in the previous curriculum (Mawarini, 2015). Learning using scientific
It is also in line with the interview results conducted with

approach is a learning process that is designed in such a way so that students actively construct concepts, laws or principles through the stages of observing (to identify problems), formulating problems, proposing or formulating hypotheses, collecting data using various techniques, analyzing data, drawing conclusions and communicating the "discovered" concept, law or principle (Mawarini, 2015). The scientific approach is used in all subjects which include extracting information by observing, asking, experimenting, then processing data or information, presenting data or information, followed by analyzing, reasoning, then concluding and creating. The learning orientation in the 2013 Curriculum context is to produce productive, creative, innovative and effective Indonesians by strengthening the attitudes, skills and knowledge. (Majid, 2014).

Research on the implementation and assessment of teaching materials have been conducted by previous researchers, such as Widayanti (2013) in her research on the implementation of "tache" in the production orale pre elementaire course. The research by Widayanti (2013) was a Classroom Action Research that emphasized the application of "tache" in learning speaking (production orale pre elementaire) in French Literature Study Program. In addition, Azis (2018) emphasized his research on the implementation of the curriculum development results. A research on the assessment of teaching materials was conducted by Defina (2019) entitled Assessment of Students on BIPA Teaching Materials Special Materials of Agriculture. From the data of the previous research, it is found that the implementation of the developed Indonesian language textbooks for grade ten in Pharmacy Vocational School is rarely conducted. Therefore, based on the background described earlier, this study answers the problem formulation on the effectiveness of the implementation of the developed pharmaceutical Indonesian language textbooks with scientific approach for the Indonesian language learning in the vocational schools in Kendal Regency.

\section{METHODOLOGY}

This study used an experimental method with a Quasi Experimental Design type with a One Shot Case Study design (Sugiyono, 2010). This study did not use a control group; there was only one group as an experimental group whose learning outcomes were analyzed. The learning outcomes were obtained from the learning by using the textbooks published by the Ministry of Education and Culture and the learning by using the developed pharmaceutical Indonesian language textbooks with scientific approach (Sugiyono, 2017). That was also the reason for choosing One Shot Case Study as the design of this study. One Shot Case Study is a design consisting of one group that is given treatment and then observing the results (Sugiyono, 2010).

The population of this study were students of the Pharmacy Vocational Schools in Kendal Regency. The sample of this study was the grade ten students from the Pharmacy Vocational Schools in Kendal Regency at a total of 97 students from five vocational schools. Data on the number of respondents from each vocational school are presented as follow.

Blue Eyes Intelligence Engineering \& Sciences Publication

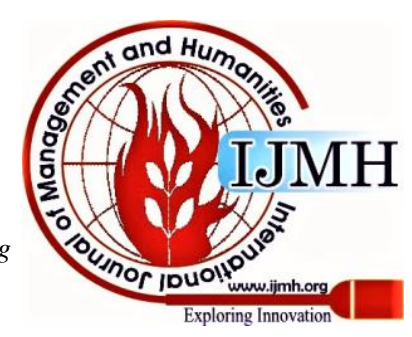


Table I: Number of Respondents of Grade Ten Students from Pharmacy Vocational Schools in Kendal Regency

\begin{tabular}{clc}
\hline No. & \multicolumn{1}{c}{ Vocational School } & $\begin{array}{c}\text { Number of } \\
\text { Students }\end{array}$ \\
\hline 1. & Azzahro, Pegandon-Kendal & 33 \\
2. & Bhakti Kencana Cepiring-Kendal & 23 \\
3. & Insan Medika Kendal & 7 \\
4. & Ngesti Widi, Jl. Laut-Kendal & 9 \\
5. & Taman Siswa, Boja-Kendal & 25 \\
\hline \multicolumn{2}{l}{ Total Respondents } & $\mathbf{9 7}$ \\
\hline
\end{tabular}

Data collection techniques used in this study were interview and test techniques. The interview technique was carried out to the grade ten teachers and students of Pharmacy Vocational Schools. The interview was conducted to find out the opinion of the grade ten teachers and students of the Pharmacy Vocational Schools regarding the developed pharmaceutical Indonesian language textbooks in terms of the materials, language and presentation. The interview took place independently with three aspects in the question guideline, namely 1) the suitability of the materials presented in pharmaceutical context, 2) the effectiveness of the language used in delivering the materials along with the assignments, 3) the integration of image layout with reading texts as well as the arrangement of the material presentation. The test technique was carried out to determine the effectiveness of learning by applying the developed Indonesian language textbooks. There were two test results applied, namely the learning outcome test after implementing the Indonesian language textbooks by the Ministry of Education and Culture and the learning outcome test after implementing the pharmaceutical Indonesian language textbook. The effectiveness of the implementation of the textbooks by the Ministry of Education and Culture and the developed pharmaceutical Indonesian language textbooks was analyzed by using the t-test technique. Meanwhile, the type of data analysis used was the paired sample t-test using calculations from the SPSS 21 application.

\section{RESULT AND DISCUSSION}

The implementation of this study aims to determine the effectiveness of the implementation of the developed pharmaceutical textbooks with scientific approach for the grade ten students of Pharmacy Vocational Schools. The results of this study are in the form of data obtained from interviews and tests of the developed pharmaceutical textbooks with scientific approach. The summary of the results of the study obtained from the interviews and the analysis of the implementation test results of the developed textbooks employing t-test by using the SPSS 21 application are presented as follow.

\section{Student and teacher responses to the developed pharmaceutical Indonesian language textbooks through interviews}

Interviews were conducted to obtain information on the developed pharmaceutical Indonesian language textbooks. The interviews were conducted after the learning activities at school to 10 students and 5 teachers in five Pharmacy Vocational Schools in Kendal Regency. The purpose of the interview was to obtain information about the weaknesses and drawbacks of the developed pharmaceutical Indonesian language textbooks that have been implemented to the grade ten students of five Pharmacy Vocational Schools in Kendal Regency. There are three components proposed in the interview, namely materials, language and presentation. The results of the interviews with 10 students and 5 teachers of grade ten from five Pharmacy Vocational Schools in Kendal Regency showed that the materials presented in the developed textbook were in accordance with the pharmaceutical context. In addition, the language used in delivering the materials and assignments was effective and understandable by the students. Furthermore, the presentation of the textbook was interesting because the textbook was arranged and presented in a chronological order as well as equipped with pharmaceutical pictures. The summary of the interview results with the teachers and students is presented in the following table.

Table II: Summary of Teacher and Student Responses on the Developed Pharmaceutical Indonesian Language Textbooks through Interviews

\begin{tabular}{lll}
\hline $\begin{array}{l}\text { Interview } \\
\text { Components }\end{array}$ & $\begin{array}{l}\text { Responses } \\
\text { Student }\end{array}$ & $\begin{array}{l}\text { Teacher } \\
\text { Materials }\end{array}$ \\
$\begin{array}{lll}\text { The materials are presented in a clear } \\
\text { order, complete, consistent and the } \\
\text { source of the materials is authentic }\end{array}$ & $\begin{array}{l}\text { Materials are in accordance with the basic competencies } \\
\text { and pharmaceutical context }\end{array}$ \\
\hline Language & $\begin{array}{l}\text { The language used is easy to } \\
\text { understand }\end{array}$ & $\begin{array}{l}\text { The language style used is communicative; the sentences } \\
\text { in the material explanation are clear; the assignment } \\
\text { instructions have used short, concise, and clear } \\
\text { sentences; the writing rules have followed PUEBI rules; } \\
\text { etc. }\end{array}$ \\
\hline $\begin{array}{l}\text { Layout and } \\
\text { Presentation }\end{array}$ & The layout of the book is interesting & $\begin{array}{l}\text { The design of the cover is attractive; the pictures, tables } \\
\text { and illustrations used are relevant; the images in the } \\
\text { reading text are in accordance with the substance of the } \\
\text { materials, etc. }\end{array}$ \\
\hline
\end{tabular}

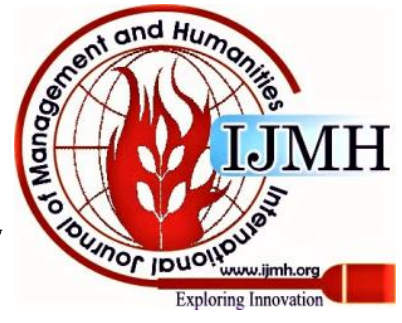


The interview consisted of 3 interview components, namely questions in terms of the materials, language, and presentation of the developed textbook. The number of respondents from the five Pharmacy Vocational Schools in Kendal Regency consisted of 5 teachers and 10 grade ten students. The 10 students consisted of 2 students (male and female) from each school, respectively. The interview with the teachers had 25 questions consisting of 11 questions on teaching materials, 9 questions on language and 5 questions on the presentation of the developed textbook. The interview with the students had 10 questions consisting of 5 questions on teaching materials, 3 questions on the language used and 2 questions on the presentation of the developed textbook.

The materials aspect is the first component that is asked in the interviews with the teachers and the students of grade ten in the Pharmacy Vocational Schools in Kendal Regency. The materials component is asked to the teachers to find out the suitability of the basic competencies with the pharmaceutical context presented in the developed textbook. The material component is also asked to the students to measure the completeness, presentation and clarity of the material explanation in the developed textbooks.

The next interview aspect is the language component. The language component is asked to all respondents in order to find out the clarity of sentences in presenting the materials, the suitability of the language with PUEBI and the communicative use of language in arranging the materials and assignments. The responses given by the teachers to the 9 questions regarding the language used in the textbook stated that the language used to deliver the materials and assignments in the developed textbook was easy to understand. The language in the textbook was communicative and the technical writing was in accordance with the PUEBI rules. This can also be seen from the student responses in answering the 3 questions related to the language used in the developed textbooks.

The last interview component was the layout and presentation component. The layout component was considered attractive and the presentation of the book in terms of the cover design and the content was also considered good. In addition to showing the attractiveness of the layout and presentation of the textbook, this component also wanted to find out the relevance of the presentation of illustrations on each subject with the reading text presented in the developed textbook. The teacher and student responses to the questions asked in terms of the layout and presentation components stated that the layout and presentation of the developed textbooks from the front and back covers were attractive because the cover displayed a pharmaceutical identity, which can attract the students to read the content. The layout design of the textbook content was also attractive. The respondents stated that the design used from the first page to the end of the textbook was consistent and had a sense of unity. The illustrations and images that were presented in each discussion as well as the reading text also reflected the content of the reading text, which was appropriate with the pharmaceutical context. For example, on page 1 of the materials about observation results report, the presented reading text was "Report on Observation Results at Sukoharjo Regional General Hospital (Pharmacy Unit)" with illustrations of all activities at the pharmacy unit in Sukoharjo Hospital.

Analysis of the implementation of the developed pharmaceutical Indonesian language textbooks through learning outcomes test

The learning outcome test results were obtained from the implementation of two textbooks, namely the Indonesian language textbook published by the Ministry of Education and Culture and the developed pharmaceutical Indonesian language textbooks with scientific approach for grade ten students of Pharmacy Vocational Schools in Kendal Regency. The learning outcomes obtained from using the Indonesian language textbooks published by the Ministry of Education and Culture are compared with the learning outcomes obtained from applying the developed textbooks to determine the effectiveness of the implementation of the developed pharmaceutical textbooks. Student learning outcomes were analyzed using the paired sample t-test technique with the help of SPSS 21. Based on the results of the data analysis, the average score and improvement obtained can be seen in Table 3 below.

Table III: Average Score and Improvement from the Implementation of the Developed Pharmaceutical Indonesian Language Textbooks

\begin{tabular}{llll}
\hline & Mean & & Improvement \\
\cline { 2 - 3 } Vocational Schools & $\begin{array}{l}\text { Indonesian language textbooks } \\
\text { from the Ministry of Education } \\
\text { and Culture }\end{array}$ & $\begin{array}{l}\text { Pharmaceutical Indonesian } \\
\text { Language Textbooks }\end{array}$ & Ims.45 \\
\hline Azzahro & 75.90 & 80.36 & 9.17 \\
Bhakti Kencana & 73.09 & 82.26 & 5.42 \\
Insan Medika & 74.86 & 80.29 & 5,77 \\
Ngesti Widhi & 74.11 & 79.89 & 4,60 \\
\hline Taman Siswa Boja & 75.91 & 80.36 & $\mathbf{5 . 8 8}$ \\
\hline Average Score & $\mathbf{7 4 . 7 7}$ & $\mathbf{8 0 . 6 3}$ & \\
\hline
\end{tabular}

The t-test results reveal that there is a difference in the average score of the learning outcomes obtained from using the Indonesian language textbooks published by the Ministry of Education and Culture with the learning outcomes obtained from using the developed pharmaceutical Indonesian language textbooks. The average score of learning outcomes obtained from applying the developed pharmaceutical Indonesian language textbooks is higher than the average score of learning outcomes obtained from

applying the Indonesian language textbooks published by the Ministry of Education and Culture. The difference that stands out from the two implementations of the Indonesian Language textbook is the learning outcomes of the students of Bhakti Kencana vocational school.

Blue Eyes Intelligence Engineering \& Sciences Publication 
The increase in score is 9.17 points, which is the highest score if compared to the increase of the other four vocational schools.

This difference is caused by various things that come from media and learning environment factors (Solikhah et al., 2017). The overall average of students' learning outcomes that apply the Indonesian language textbooks by the Ministry of Education and Culture is 74.77. It is lower than the average score of the students' learning outcomes that apply the pharmaceutical Indonesian language textbooks (80.63). This explains that the teaching materials that are relevant to the student background are more effective to support the students' learning success. Students' learning success is indicated by an increase in the student learning outcome scores.

Exposure on the average learning outcomes applying the two Indonesian language textbooks in each school and the whole schools can conclude that the average learning outcomes by applying the pharmaceutical Indonesian language textbooks are higher than the learning outcomes by applying the Indonesian language textbooks by the Ministry of Education and Culture. This means that the pharmaceutical Indonesian language textbook, which is a textbook developed by the researchers, is good and can be used as a textbook for learning Indonesian language in Pharmacy Vocational Schools. The developed pharmaceutical Indonesian language textbook presents materials that are presented in a pharmaceutical context so that they can help students of Pharmacy Vocational Schools to understand the content of the materials.

Furthermore, based on the results of the analysis of the scores for each vocational school with the t-test at the significance level of 0.005 , it was found that the $t_{\text {count }}$ was bigger than the $t_{\text {tabel }}$ in terms of the student learning outcomes at Azzahro Vocational School ( $\mathrm{t}_{\text {count }}$ 8.906 $>\mathrm{t}_{\text {tabel }}$ 2.037), Bhakti Kencana Vocational School ( $\mathrm{t}_{\text {count }}$ 7.345 $>\mathrm{t}_{\text {tabel }} 2.074$ ), Insan Medika Vocational School ( $\left.t_{\text {count }} 7.550>t_{\text {tabel }} 2.447\right)$, Ngesti Widhi Vocational School ( $\mathrm{t}_{\text {count }} 4.772>\mathrm{t}_{\text {tabel }} 2.306$ ), and Taman Siswa Boja Vocational School ( $\mathrm{t}_{\text {count }} 5.858>\mathrm{t}_{\text {tabel }}$ 2.067). The output results of paired samples test show that the Sig. value (2-tailed) of each is of 0.000 , which is less than $0.005(0.000<0.005)$; meaning that the results of the developed pharmaceutical Indonesian textbooks are effective. The detailed t-test results are presented in Table 4 below.

Table IV: T-test Results of the Effectiveness of the Developed Pharmaceutical Indonesian Language Textbooks with Scientific Approach

\begin{tabular}{ccccc}
\hline Vocational School & tcount & ttable & df & sig. \\
\hline Azzahro & 8.906 & 2.037 & 32 & .000 \\
Bhakti Kencana & 7.345 & 2.074 & 22 & .000 \\
Insan Medika & 7.550 & 2.447 & 6 & .000 \\
Ngesti Widhi & 4.772 & 2.306 & 8 & .000 \\
Taman Siswa Boja & 5.858 & 2,067 & 24 & .000 \\
\hline
\end{tabular}

Based on the table above, it is found that the sig. value is of $0.000<0.005$; this means that $\mathrm{H}_{1}$ is accepted and $\mathrm{H}_{0}$ is rejected. In other words, there is a significant difference in the student learning outcomes that use the developed pharmaceutical textbooks with the student learning outcomes that use the Ministry of Education and Culture's textbooks. Based on the results of the t-test, it can be concluded that the implementation of the developed pharmaceutical textbooks with scientific approach in learning Indonesian language is more effective.

The implementation of the developed Indonesian language textbooks with scientific approach for grade ten students of Pharmacy Vocational Schools helps the students to familiarize themselves with the things related to pharmacy. The pharmaceutical Indonesian language textbooks were developed by presenting the pharmaceutical context throughout the textbooks. The test result data show that by implementing the developed pharmaceutical Indonesian language textbooks, the grade ten students of the Pharmacy Vocational Schools obtained above average scores, which means that they reached the targeted minimum completeness criterion. The results of the implementation also show that the developed pharmaceutical Indonesian language textbook is feasible. However, some parts of the textbook still need to be improved and refined. Improvements to the developed textbooks in terms of the materials, language and presentation components are continuously conducted. Revisions to perfect the substance must continue to be done (Solikhah, 2017:43).

\section{CONCLUSION}

The implementation results show that the developed pharmaceutical Indonesian language textbooks with scientific approach for grade ten students of Pharmacy Vocational Schools in Kendal Regency is effective. The effectiveness of the developed pharmaceutical Indonesian language textbooks can be seen from the interview and test results. It can also be seen from the calculation of t-test results using the paired sample test with SPSS 21 . The scores of student learning outcomes using the Ministry of Education and Culture's textbooks and the scores of student learning outcomes using the pharmaceutical textbooks at each vocational school have various increase. The increase in the average score of each vocational school was 1) 4.45 at Azzahro Vocational School, 2) 9.17 at Bhakti Kencana Vocational School, 3) 5.42 at Insan Medika Vocational School, 4) 5.77 at Ngesti Widhi Vocational School, and 5) 4.60 at Taman Siswa Boja Vocational School. The increase in the score proves that the implementation of the developed pharmaceutical Indonesian language textbooks with scientific approach for grade ten students of Pharmacy Vocational School is effective because it has an effect on increasing the scores of Indonesian language learning outcomes for almost all grade ten students of Pharmacy Vocational Schools in Kendal Regency.

Blue Eyes Intelligence Engineering \& Sciences Publication

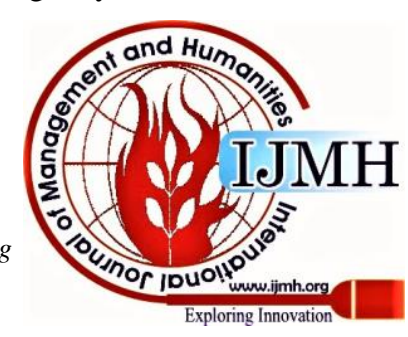




\section{Implementation of the Developed Pharmaceutical Indonesian Language Textbooks with Scientific Approach in Indonesian Language Subject in Pharmacy Vocational Schools, Kendal Regency}

The limitation of this study lies in the absence of a control group, which may provide a possible outcome perspective that supports the study or vice versa.

\section{ACKNOWLEDGEMENT}

Researchers would like to thank The Ministry of Research, Technology, Republic of Indonesia, Sanata Dharma University, and Pharmacy Vocational Schools in Kendal Regency for supporting this research.

\section{REFERENCES}

1. Agustina, P. (2015). Pengembangan PCK Mahasiswa Calon Guru Biologi FKIP Universitas Muhammadiyah Surakarta Melalui Simulasi Pembelajaran. JPPI, 1, 15.

2. Azis, R. (2018). Implementasi Pengembangan Kurikulum. Inspiratif Pendidikan, 7 (1), 44. https://doi.org/10.24252/ip.v7i1.4932

3. Banowati, E. (2007). Buku Teks dalam Pembelajaran Geografi di Kota Semarang. Jurnal Geografi, 4.

4. Defina. (2019). Assessment of Student on BIPA Teaching Materials Special Materials of Agriculture. Jurnal Litera, 18, 163.

5. Eriyanti, R. W. (2018). Pengembangan Bahan Ajar Keterampilan Berbicara Interaktif bagi Mahasiswa. Kembara: Jurnal Keilmuan Bahasa, Sastra, dan Pengajarannya, 3 (1), 98. https://doi.org/10.22219/kembara.vol3.no1.98-106

6. Iskandar, I., Budijanto, B., \& Amirudin, Ach. (2016). Pengembangan Buku Teks Geografi dengan Struktur Penulisan Ensiklopedia. Jurnal Pendidikan: Teori, Penelitian, dan Pengembangan, 1(2), 137-143. Retrieved

http://journal.um.ac.id/index.php/jptpp/article/view/6114/2571

7. Jayanti, R. (2019). Pengembangan Kompetensi Kebahasaan dalam Menulis Teks Cerpen Sejarah di MAN 7 Jombang. Kembara: Jurnal Keilmuan Bahasa, Sastra, dan Pengajarannya, 5.

8. Laily, D. N. (2016). Efektivias Penggunaan Buku Siswa Kurikulum 2013 dan Buku Paket Bahasa Indonesia BSE dalam Pembelajaran Membaca Siswa Kelas Satu SD Negeri Sumberjo Kecamatan Purwosari Kabupaten Kediri Tahun Ajaran 2015/ 2016. Jurnal NOSI, 4(2).

9. Majid, Abdul dan Chaerul Rochman. (2014). Pendekatan Ilmiah dalam Implementasi Kurikulum 2013. Bandung: PT Rosdakarya.

10. Mastun. (2017). Efektivitas Penggunaan Buku Ajar Elektronika Lanjut Berbasis Eksperimen. Jurnal Pendidikan Informatika, 6 (1), 95-101.

11. Mawarini, E. (2015). "Pelaksanaan Pembelajaran dengan Pendekatan Saintifik (Saintifik Approach) di Kelas IIB Sekolah Negeri Serayu Yogyakarta". S1 Thesis. Universitas Negeri Yogyakarta.

12. Mursida, I. (2017). Pengembangan Buku Ajar Bahasa Indonesia Bermuatan Nilai-Nilai Karakter Menggunakan Model Pembelajaran Berbasis Masalah. EDU-KATA, 4.

13. Nugroho, A., Lazuradi, D.R. \& Murti, S. (2019). Pengembangan Bahan Ajar LKS Menulis Pantun Berbasis Kearifan Lokal Siswa Kelas VI SMP Xaverius Tugumulyo. Kembara: Jurnal Keilmuan Bahasa, Sastra, dan Pengajarannya, $\quad 5 \quad$ (1), 1 https://doi.org/10.22219/kembara.vol5.no.1.1-12.

14. Rochmayanti, D. S. (2012). Pengembangan Buku Teks Bahasa Indonesia Berbasis Budi Pekerti Luhur untuk Siswa Kelas 4 Semester 2 di SDN 1 Kedunganyar Kecamatan Wringinanom Kabupaten Gresik. Jurnal Unesa, 1 (1), 216

15. Sembiring, R. J. B. (2018). Pengembangan Buku Ajar Pragmatik Edukasional Terintegrasi Konteks Situasi dan Sosial bagi Mahasiswa.

16. Setiawati, I. (2016). Strategi Meningkatkan Kemampuan Menulis Karangan Kreatif pada Siswa Kelas 4 dan 5. Dinamika Penelitian, 16.

17. Sitepu. (2005). Memilih Buku Pelajaran. Jurnal Pendidikan Penabur, 14.

18. Solikhah, A., Waluyo, H.J., \& Rohmadi, M. (2017). Implementasi Kurikulum 2013 pada Pembelajaran Bahasa Indonesia (Studi Kasus Kelas X di SMA Negeri 1 , 2 , dan 1 Bae Kudus). Jurnal Magistra, 101, 33-44.

19. Sugiyono. (2017). Metode Penelitian Pendidikan Pendekatan Kuantitatif. Bandung: Alfabeta.

20. Widayanti, D. V. (2013). Implementasi Tache pada Mata Kuliah Production Orale Pre Elementaire. Jurnal Lingua, 9 (2), 56-61.

\section{AUTHORS' PROFILE}

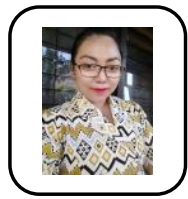

Angela Diyansih Wisesa Chuntala, M.Pd. holds an M.Pd., Indonesian Language Education, works as a teacher at the Indonesian Health Vocational School in Papua and is currently conducting higher education research with the Ministry of Research, Technology and Higher Education. His thesis produced an Indonesian in Kendal Regency. anguage textbook for Pharmacy Vocational High Schools

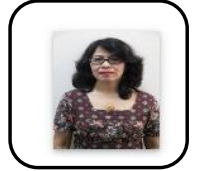

Dr. Yuliana Setyaningsih, M.Pd., was born in Surakarta on October 1, 1963. She serves as the Lecturer of Indonesia Language and Literature Education Study Program, Faculty of Teachers Training and Education, Sanata Dharma University, Yogyakarta. She served as the Head Department of the Indonesian and Literature Study Program for two periods starting from 2009 until 2017. She graduated from the Doctorate Program of Indonesian Education University in Indonesian Education Teaching Study Program in January 2007. The textbooks during her doctorate tenure are: Fonologi dalam Bahasa Indonesia (Universitas Sanata Dharma Press, Yogyakarta, 2014), Pragmatik: Fenomena Ketidaksantunan Berbahasa (Erlangga Publisher Jakarta, 2016) as the co-writer, Menulis Artikel Jurnal: Panduan Mencipta Karya Ilmiah Bermutu dengan Pengembangan Argumentasi Berperspektif Stephen Toulmin (Amara Books Publisher Yogyakarta, 2018) Model Peningkatan Kualitas Argumen Paragraf-paragraf Argumentatif Bagian Pembahasan Artikel Jurnal Terakreditasi, Amara Books Publisher Yogyakarta, 2017), Kefatisan Berbahasa: Studi fenomena kebahasaan dalam perspektif sosiokultural dan situasional, Amara Books Publisher Yogyakarta, 2017) as the co-writer. She did her thoughts in Indonesian Language Teaching, Evaluation, Curriculum Development, and Critical Writing based on Toulmin's Model and they have been exposed in various national and international forums documented in various proceedings and journal articles. Joining with her colleague, she also did some researches on Pragmatics, Sociopragmatics, and Ecolinguistics.

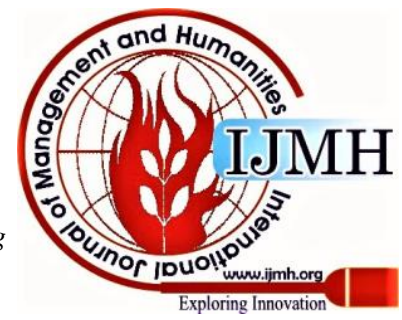

